\title{
Marketinaren filosofiaren eta artearen ikuspegi erromantikoaren arteko gatazka
}

\author{
Aitziber Núñez Zabaleta eta Unai Núñez Zabaleta* \\ Euskal Herriko Unibertsitatea (UPV/EHU). Ekonomia eta Enpresa Fakultatea \\ * Bigarren Hezkuntzako irakaslea. Geografia eta Historia Saila
}

\begin{abstract}
Arte-arloko marketinaren erabileraren ikuspegi ezberdinak aztertuko dira lan honetan. Izan ere, Arte Ederren ezaugarri bereziak direla-eta, historian zehar jarrera kontrajarriak sortu dira adituen artean, marketin-funtzioak artelanaren ekoizpenaren zein fasetan erabili behar diren hain zuzen ere, eta bi korronte nagusi sortu dira. Alde batetik, marketina merkaturatze-tresna soiltzat erabiltzea proposatzen dutenak, artelana amaituta dagoen momentutik aurrera eta ez sortze-prozesuan, produkturako orientazioa deitua. Eta bestalde, marketinaren merkatu-orientazioa defendatzen dutenak, marketina artelanaren sortze-prozesuaren lehen etapatik presente egon behar duelako ideia, eta marketin orokorraren filosofiarekin bat datorrena. Azken finean, autoreak bi ikuspuntuen arteko oreka bilatzen saiatu dira, arte-arlora zuzendutako marketin propio bat proposatuz, arteen marketin kontzeptua hain zuzen ere.
\end{abstract}

GAKO-HITZAK: Produkturako ikuspegia · Merkarturako ikuspegia · Orientaziodilema · Ideia erromatikoa - Arteen marketina - Merkataritza eta arteen oreka.

\section{Tension between marketing philosophy and the romantic view of art}

This work examines the different approaches in the use of marketing in the field of art. Because of the specific features of fine arts, there have been opposing positions among experts over time. This paper explores the two main contrasting points of view. On the one hand, some experts propose to use marketing tools only to bring the art product to the market once the art work is finshed rather than in the creation and development stage, this idea is known as "product-led". On the other hand, the idea of who say that marketing tools have to be aplied from the first stage, that is to say, from the conception of the art product, in line with marketing philosophy, this idea is known as "market-led". After all, many authors will come to seek a balance between the two approaches, proposing an specific marketing model customized to the art field

KEY WORDS: Product-led · Market-led · Orientation dilemma $\cdot$ Romantic view · Arts marketing · Art and commercial balance. 


\section{Sarrera}

Arte hitzak jatorriz edozein modutako trebetasuna esan nahi du (Harluxet, 2018), definizio ugari dituelarik; haien artean "gaur egun artetzat jotzen dugu gizakiaren sormenaren ia edozein adierazpen». XX. mendean bederatzi arte mota bereizi ziren: arkitektura, dantza, eskultura, musika, pintura, literatura, zinema, argazkigintza eta komikia. Auñamendi Euskal Enziklopediaren arabera (2018), gaur egun, diseinua, publizitatea, moda edota gastronomia ere adierazpen artistikotzat jo daitezke. Beraz, artearen kontzeptua oso zabala da. Lan honetan, hala ere, soilik pintura eta eskulturaren merkatuak jorratuko dira, arte plastikoak alegia.

Historian zehar, artearen ikuspegi erromantikoa dela-eta, arte-merkatuaren eta marketinaren filosofiaren arteko bateraezintasunak agertu dira, eta ondorioz jarrera ezberdinak sortu dira adituen artean. Azken mendean adituek izan dituzten jarrerak aztertzea da lan honen helburua.

\section{Arteen marketina: kontzeptua}

Arteen marketina artistaren lana merkatura hurbiltzeko asmoz jaio zen. Marketinaren helburu nagusia artistek artearen merkatuan epe luzerako posizio optimoa lortzea da. Nahiz eta gaur egun jarrera babestuena merkatura bideraturiko marketina izan, ikuspuntu eta iritzi kontrajarriak sortu dira azken lau hamarkadetan.

Peraltak (2013) dio, artearen jatorria espresio moduan, marketinaren beraren jatorria izan zela. Gizakia kobazuloetan marrazten hasi zen momentuan marketinkanpaina bat sortu zen, marrazlearen sormenaren bitartez beste gizakiei zerbait adierazteko helburuarekin.

American Marketing Association delakoaen arabera (2008), marketina zera da: Bezero, bazkide eta gizartearentzako balioa duten eskaintzak sortzeko jarduera eta prozesu multzoa, eta komunikatzeko, banatzeko nahiz trukatzeko funtzioa duena. Marketin kontzeptua bi ikuspegitatik uler daiteke: ikuspegi filosofikoa, marketina erakundea kudeatzeko modu bat da, eta ikuspegi funtzionala, marketina enpresaren funtzio, tresna edota teknika multzo bat da. Gaur egun, gero eta gehiago hitz egiten da marketina prozesu gisa ulertu behar dela, hau da, enpresa osoaren lana burutzeko eta kudeatzeko modu bat bezala.

Bestalde, marketin-funtzioaren arabera, marketinak bi dimentsio ditu: marketin estrategikoa eta operatiboa. Dimentsio estrategikoa, artearen merkatuaren beharrei buruzko informazioaren bilaketan eta analisian datza, eta, marketin operatiboa, berriz, aurrera eraman beharreko ekintza-planaren ezarpenean datza, eta marketinaren mix edo marketinaren lau P-ak izenez ezaguna da: produktua (product), prezioa (price), banaketa (place) eta komunikazioa (promotion).

Walker, Etzel eta Stantonek (2007) marketinaren filolosofia denboran zehar gertatu zen prozesu gisa azaldu zuten eta bi ikuspuntu edo orientazio bereizi zituzten: produkturako orientazioa eta merkaturako orientazioa. Produkturako orientazioaren ikuspuntutik, marketinaren funtzioa produktuak, behin ekoiztuta daudenean, 
merkatura hurbiltzea da, kontsumitzaileek eros ditzaten. Merkaturako orientazioaren ikuspuntutik, berriz, marketinaren funtzioaren lana kontsumitzaileen beharrak eta desirak ezagutzea da, ondoren haientzako produktuak ekoizteko asmoarekin.

Kotlerrek (1999) arteari egokitutako marketinaren definizioa eman zuen: «Arteen marketinak prozesu sozial bati egiten dio erreferentzia, pertsona eta erakundeen nahien eta beharren asebetetzera zuzenduta, hori lortzeko artelanen sorkuntza eta eskualdaketa lehiakorra eta boluntarioa egin behar delarik». Marketina funtzio sozial batera bideraturik dagoela adierazten du, eta sormenera, komunikaziora eta bezeroei balioa ematera bideratutako prozesu multzoa dela uler daiteke. Aldi berean, helburua bezeroarekin harremanak kudeatzea izango litzateke, artistaren onurarako, baita interes-talde eta gizartearen onurarako ere. Marketinaren filosofiak merkatuaren beharrak asetzea bilatzen du produktuaren sortze-prozesuaren lehen etapatik. Zenbait aditu filosofia horren aurka agertu dira, merkatuak artearen sormenean eta artistaren inspirazioan eraginik izan behar ez duela azpimarratuz, artearen berezitasun eta purutasunean eragingo lukeelako. Marketina produktuaren sortze-prozesuaren lehen etapatik eta merkaturen beharrak asetzea bilatzen duen teknika multzo bezela ulertzen denean sortzen da, beraz, eztabaida. Esan bezala, aditu batzuen ustetan merkatuak ez luke eraginik izan behar artelanaren ekoizpenfasean, horrek artistaren inspirazioan eragin negatiboa izango lukeelako.

Hurrengo atalean, arteen marketinaren eboluzioan izan diren ikuspegi desberdinak azaltzen dira, zeinak marketinaren bi ikuspegi nagusiekin lotuta baitaude: produkturako orientazioa eta merkaturako orientazioa.

\section{Marketinaren garapena artean eta kulturan}

Kultura edo arteen marketinaren kontzeptua ondo ulertzeko, ezinbestekoa da lehenik kulturaren marketinak denboran zehar izan duen garapena azaltzea zenbait autoreren ikuspegiaren azterketaren bitartez.

Arteen marketinari buruzko lehen aipamena 1970eko hamarkadan egin zen Britania Handiko Arts Councilen eskutik (1976), eta hurrengo hamarkadetatik gaur egun arte, kontzeptu horrek iritzi ezberdinak sortu ditu. Leek (2005) hiru etapatan bereizten du arteen marketinaren eboluzia. Lehenengo etapan, marketina merkatu berrietara zuzentzeko tresna multzo gisa erabiltzen da. Bigareen etapan, 1980ko hamarkadan, marketinaren erabilera tresna soila izatetik prozesu multzo bat izatera pasatuko da, hau da, erakundearen kudeaketa osoa izango du kontuan. Hirugarren etapan, 1990etik gaur egun arte, arteen marketina kudeaketa-filosofia gisa ulertuko da, merkatuaren beharren menpe gelditzen delarik.

Arte-arloko marketinaren orientazio-dileman sakontzerakoan, eztabaida handiak sortu dituen gaia dela nabarmendu daiteke. Horren arrazoia da marketinaren kontzeptuak arteen ikuspegi erromantikoarenkin talka egiten duela pentsatzea. Suspertzen ari diren herrialdeetan arte- eta kultura-arloak ez dira ekonomiamerkatuen barnean hautematen, ez baitago artelanaren eta merkatuaren arteko loturarik (Klamer, 2016). Autore batzuek marketina produktura bideratu behar dela argudiatu dute (Diggle, 1976; Robbins eta Verwey, 1982; Maitland eta Meddick, UZTARO 112, 5-18 
1990), produkturako orientazioaren ikuspegia hain zuzen ere. Ikuspuntu horren arabera, marketin-tresnak behin produktua diseinatuta dagoenean merkaturatzefuntzioa betetzeko erabili beharko dira, «ez-marketin» deitua izan dena. Modu horretan, merkatuak ez du eraginik izango artistaren inspirazio- eta sormenprozesuan. Bestalde, beste autore batzuek marketinaren erabilera integratua defendatzen dute, etapa guztietan presente egon behar duelarik, baita produktuaren sortze-etapan ere. Ideia horren arabera, artelanak merkatu eta bezeroen beharretan oinarrituta sortua izan behar du, alegia marketinaren filosofiak defendatzen duena.

Etapa ezberdin hauen laburpena 1. taulan ikus daiteke, bertan autore bakoitzak duen ikuspuntua ordena kronologikoan agertzen da. Jarraian, arteen marketinaren eboluzioa sakonago aztertuko da, taula honetan erakutsitako ikuspuntu ezberdinen garapena eta ezaugarriak azalduz.

1. taula: Arteen marketinaren eboluzioa.

\begin{tabular}{|c|c|c|c|}
\hline $\begin{array}{c}\text { Arteen marketinaren } \\
\text { etapak }\end{array}$ & Autorea & Marketinarekiko erlazioak & $\begin{array}{l}\text { Marketinaren } \\
\text { aplikazioa }\end{array}$ \\
\hline Tresna multzo gisa & $\begin{array}{l}\text { Arts Council } \\
\quad(1976)\end{array}$ & $\begin{array}{l}\text { Sektore komertzialetik } \\
\text { organizazio artistikoetara } \\
\text { erraz transmitigarriak diren } \\
\text { teknikak. }\end{array}$ & Artea lehenik. \\
\hline Tresna multzo gisa & $\begin{array}{l}\text { Diggle } \\
(1976)\end{array}$ & $\begin{array}{l}\text { Marketinaren erabilera } \\
\text { merkatu-ikerketa, promozio, } \\
\text { merchandising eta } \\
\text { banaketarako. }\end{array}$ & Artea lehenik. \\
\hline Prozesu-sistema & $\begin{array}{l}\text { Robbins } \\
\text { eta Verwey } \\
(1982)\end{array}$ & $\begin{array}{l}\text { Marketinaren erabilera } \\
\text { erabakiak hartzeko. }\end{array}$ & Artea lehenik. \\
\hline Prozesu-sistema & $\begin{array}{l}\text { Wyatt } \\
(1983)\end{array}$ & $\begin{array}{l}\text { Marketinaren erabilera } \\
\text { erabakiak hartzeko. }\end{array}$ & Artea lehenik. \\
\hline Prozesu-sistema & $\begin{array}{l}\text { Maitland eta } \\
\text { Meddick } \\
(1990)\end{array}$ & $\begin{array}{l}\text { Marketinaren erabilera } \\
\text { erabakiak hartzeko prozesu } \\
\text { gisa. }\end{array}$ & $\begin{array}{l}\text { Produkturako } \\
\text { orientazioa } \\
\text { (artistaren } \\
\text { sormena lehenik). }\end{array}$ \\
\hline Prozesu-sistema & $\begin{array}{l}\text { Arts G. L. } \\
\text { (1989) }\end{array}$ & $\begin{array}{l}\text { Marketinaren erabilera } \\
\text { erabakiak hartzeko. }\end{array}$ & $\begin{array}{l}\text { Produkturako } \\
\text { orientazioa } \\
\text { (artistaren } \\
\text { sormena lehenik) }\end{array}$ \\
\hline $\begin{array}{l}\text { Prozesu-sistema - } \\
\text { Filosofia }\end{array}$ & $\begin{array}{l}\text { Rodger } \\
(1987)\end{array}$ & $\begin{array}{l}\text { Marketinaren erabilera } \\
\text { erabakiak hartzeko, hala ere, } \\
\text { filosofia gisa ikusten hasiko } \\
\text { da. }\end{array}$ & $\begin{array}{c}\text { Marketina neutrala } \\
\text { da. }\end{array}$ \\
\hline Filosofia & $\begin{array}{l}\text { Hirschman } \\
\text { (1983) }\end{array}$ & $\begin{array}{l}\text { Kontsumitzailearen definizioa } \\
\text { zabaltzen du, ekoizlea } \\
\text { eta gainerako artistak } \\
\text { barneratzen ditu. }\end{array}$ & $\begin{array}{l}\text { Artea lehenengo } \\
\text { (artista da bere } \\
\text { produktuen lehen } \\
\text { kontsumitzailea). }\end{array}$ \\
\hline
\end{tabular}




\begin{tabular}{|c|c|l|c|}
\hline Filosofia & $\begin{array}{c}\text { Colbert eta } \\
\text { Cuadrado } \\
(2003)\end{array}$ & $\begin{array}{l}\text { Marketina merkatura } \\
\text { zuzentzen da, behin } \\
\text { produktua diseinatuta. }\end{array}$ & $\begin{array}{c}\text { Produktura } \\
\text { orientatua (artea). }\end{array}$ \\
\hline Filosofia & $\begin{array}{c}\text { Scheff } \\
\text { eta Kotler } \\
(1996)\end{array}$ & $\begin{array}{l}\text { Kontsumitzailearen beharren } \\
\text { eta integritate artistikoaren } \\
\text { arteko balantza. }\end{array}$ & $\begin{array}{c}\text { Artearen eta } \\
\text { merkatuaren } \\
\text { arteko oreka. }\end{array}$ \\
\hline Filosofia & $\begin{array}{c}\text { Kotler eta } \\
\text { Scheff } \\
(2004)\end{array}$ & $\begin{array}{l}\text { Marketina merkatura } \\
\text { zuzenduko da, produktua } \\
\text { diseinaturik dagoenean. }\end{array}$ & $\begin{array}{c}\text { Artearen eta } \\
\text { merkatuaren } \\
\text { arteko oreka. }\end{array}$ \\
\hline Filosofia & $\begin{array}{c}\text { Solomon } \\
(2004)\end{array}$ & $\begin{array}{l}\text { Marketinaren integrazioa } \\
\text { produkzio-etapa guztietan. }\end{array}$ & $\begin{array}{c}\text { Merkatura } \\
\text { zuzenduriko } \\
\text { marketina. }\end{array}$ \\
\hline Filosofia & $\begin{array}{c}\text { Boorsma } \\
(2006)\end{array}$ & $\begin{array}{l}\text { Kontsumitzailea ko- } \\
\text { produzitzaile gisa. }\end{array}$ & $\begin{array}{c}\text { Merkatura } \\
\text { zuzenduriko } \\
\text { marketina. }\end{array}$ \\
\hline
\end{tabular}

Iturria: Lee (2005) eta Flores, Pérez eta Blanco (2010: 25) datuekin egindako taula. Iturria: Lee (2005) eta Flores, Pérez eta Blanco (2010: 25) datuekin egindako taula.

\subsection{Lehenengo etapa: marketina tresna multzo gisa}

70eko hamarkada inguruan, marketinaren erabilera irabazi-asmorik gabeko erakundeetara hedatu zen lehen aldiz. Aldi berean, sektore artistikora zuzentzeko ideia hedatzen hasi zen Britainia Handian Arts Councilen eskutik (1976). Merkataritza-arloan erabiltzen ziren marketin-teknika edo -tresna multzoa arlo artistikora hedatzeko aukera antzeman zen, eta, horrela, publiko zabalago batera helduta irabaziak handitzeko egokiera ere (Diggle, 1976: Lee, 2005).

Garai horretan, artearen marketinaren kontzeptua sortzen da, artisten autoritateaitorpenerako eta autonomia izateko abiapuntu bihurtzen delarik. Diggleren ustetan (1976), produktu artistikoa eta autorea bera, marketin-funtziotik kanpo geratu behar dira. Beraz, marketinaren esku, soilik lan komertziala uztea defendatzen du, lan hori bitartekariei delegatuz (galeriak eta enkante-etxeak). Bitartekarien funtzioak produktuen sustapena eta banaketa izan behar du, artelana artistaren eskuetatik publikoaren eskuetara helaraziz. Horretaz gain, merkatariek arte-kontsumitzaile berrien bila irtetea aldezten dute, publiko handiagoa erakartzeko asmoz. Ondorioz, marketinaren funtzio zehatzak mugaturik geratzen dira komunikazio-lanetara, publizitatera, sustapenera, merchandisingera, banaketara eta merkatu-ikerketara beste batzuen artean, betiere behin produktua bukatua dagoenean. Ideia hau produkturako orientazioa bezala ezagutzen da marketin-arloan. Produkturako orientazioaren ikuspuntuak kritika ugari jaso zituen, horien artean Raymond eta Greyser (1978) autoreena, aurreko ikuspegiak marketinean zituen mugez jabetuta, haien iritziz, ezin da marketina komunikaziorako eta bezeroak erakartzeko modu soil gisa erabili. Haien ekarpenen artean, arte-arloan ere marketina kudeaketa-prozesu gisa ulertu behar delako ideia dago. Hala eta guztiz ere, haien proposamenak ez dira kritikatzen ari direnen aldean oso ezberdinak. Autore horien pentsaerak indarra hartzen jarraituko zuen 80ko hamarkadan. 


\subsection{Bigarren etapa: marketina prozesu-sistema gisa}

1980ko hamarkadan irabazi-asmorik gabeko erakundeen marketinarekiko interesa agerian gelditzen da (Lee, 2005). Britania Handiko gobernuak arte-erakundeei finantzazioa murriztu zien, merkataritza-pentsamoldea garatu zezaten marketintresnen erabileraren bidez. Lehenengo aldiz arte-arloan, bezeroa negozioaren abiapuntu bezala proposatu zen, ordura arte pasiboa kontsideratua izan zen audientzia bati aurre egiteko.

Garai horretan, nahiz eta arte-eskaria handitu, arteen marketinaren teorizazioa pausatuki garatzen da. Estatu Batuetan akademia-arloan gai honen inguruan testu anitz idazten diren bitartean, Britania Handian gida praktikoak garatzen dituzte, non artearen marketina erakunde baten kudeaketaren prozesu gisa antzematen hasten den. Hamarkada horretan lehen aldiz, arteen marketina kudeaketa-prozesu sistema gisa proposatzen da, Robbins eta Verweyk (1982) erakunde artistikoei marketina aplikatzeko gidaliburua argitaratzen dutenean. Aipatutako autoreek marketina honela definitzen dute: «Prozesu koordinatu bat, zeinean baliabideak produktu egoki bat proposatzeko erabiltzen diren, helburu den audientzia (target) bati zuzenduta eta erakundearen helburuak lortzeko asmoz"».

Autore batzuek marketina erabakiak hartzeko prozesu erabilgarri gisa kontsideratzen dute (Rodger, 1987; Arts G. L., 1989; Maitland eta Meddicken,1990). Hala ere, oraindik, aurreko ikuspegien arrastoak geratzen dira. Leek (2005) esan moduan, «prozesuen marketinaren teoriaren helburuetako bat merkatura orientaturik egotea da, bezeroen nahien identifikazioari aurre hartuz eta haien beharrak asebetetzeko erabakiak hartuz». Ordura arte testu-argitalpenetan nekez kontsideratzen da merkaturako orientazioa, marketin-tresnak aplikatzen dira behin produktua diseinaturik eta amaiturik dagoenean, produkturako orientazioa bezala ezagutzen dena.

Mokwa, Dawson eta Prieveren (1980) ustetan, arteen marketinaren rola artistaren kreazioa publiko egokiari bideratzea da, baina artistari artelana nola egin behar duen agindu gabe. Searles (1980) ildo beretik doa, artearen sektorean marketinaren elementu batzuk soilik direla aplikagarri defendatuz, merkatuen segmentuen identifikazioa eta haiengana iristeko bidea hain zuzen ere. Bestalde, desegoki ikusten du kontsumitzaileen gustuek eta preferentziek produktuaren diseinuan eta garapenean eragina izatea; izan ere, hori artistaren lana da. Hamarkada horretako salbuespen bakarra Melilloren (1983) eskutik dator, arte eszenikoei buruzkoa bada ere, horrek marketinaren printzipioak (prozezu eta teknikak) artistaren prozesu kreatiboan integratu eta erabili behar direla adierazten du. Ideia hori beste autore batzuen artean indarra hartzen joan zen 90eko hamarkadan zehar arteen marketinaren azken etapara heldu arte.

\subsection{Hirugarren etapa: marketina filosofia gisa eta orientazio-dilema}

1990eko hamarkadan arteen marketinaren kontzeptuak aldaketa nabarmena izan zuen, marketina jada ez da diseinaturik eta landurik dauden produktuak merkaturatzeko tresna multzo soiltzat antzematen, baizik eta erakunde-filosofia bezala ulertuko dute garaiko akademikoek. Ikuspegi horren arabera, marketinak 
produktuaren diseinuan eta produkzioan ere presente egon behar du, merkaturako orientazioa bezala ezagutzen den ideia. Arte-arloan diharduten erakundeek bezeroen nahiak erabakia hartzeko prozesuaren erdian jarriko dituzte. Momentu horretan, hain zuzen ere, marketin kontzeptuaren eta artearen ideia erromantikoaren arteko talka sortuko da. Arteen marketinak orientazioaren dilema saihetsezinarekin topo egiten du, eta kultura edo arteen marketinaren paperari buruz aipatutako bi ikuspegien (produkturako eta merkaturako orientazioa) arteko eztabaida piztuko da. Alde batetik, arte-produktuaren defendatzaileak daude, zeinek, aurretik jorratutako autoreen antzera, produktu artistikoa lehenetsiko baitute merkatu-bezeroen nahien aurretik. Bestalde, marketinaren merkaturako orientazioa defendatzen dutenak daude, zeinek pentsatzen baitute marketinak artelanaren lehenengo etapan ere (diseinu eta sortze) presente egon behar duela eta artelana bezeroen gustu eta nahien arabera sortu behar dela.

Hirschman (1983) merkaturako orientazioaren aurka agertzen da, hau da, marketina merkatura eta bezeroen nahietara bideratuta aplikatzearen aurka. Autore horrek prozesu kreatiboaren eta marketinaren arteko independentzia aldezten du bere «Aesthetics, Ideologies and limits of the Marketing Concept» idatzian. Artisten ideia erromantikoan oinarriturik, artistek edertasunaren kontzeptua, zirrarak eta ideia artistikoak espresio moduan sortzen dituzte. Marketinaren teoriak produkzio artistikoaren berezitasunak kontsideratu beharko lituzke. Beste hitz batzuetan, lehenik eta behin produktua sortu, ondoren produktua publikora aurkeztu, eta haiek erabakiko dute onartu edo baztertzen duten. Autore horren ustez, egileak edo artistak publikoaren parte izan behar du, horrela publikoaren kontzeptua zabalduko da, askotan artista baita gustuak sortzen dituena. Ikuspegi honen arabera, artistak euren artelanak kontsumitzen dituzten lehen pertsonak dira eta euren lana onargarritzat emanez gero, orduan gainontzeko publikoaren esku jarriko dituzte.

Voss eta Vossen (2000) ikerketa ere jarrera horren barnean kokatu daiteke. Haiek ere, merkatura zuzenduriko arteen marketinaren aurkako iritzia dute. Beste lan batzuek ere, ildo beretik egiten dute kritika (Caust, 2003; Nielsen, 2003) eta marketinaren filosofiaren tresnen erabilerak meritu artistikoa sakrifikatzeko arriskua dakarrela diote. Horrela, enpresa-ikuspegi batek merkatura orientaturiko produktuak ekoiztea ekarriko luke eta agian hori ez da kontsumitzaileek nahi edota behar dutena. Ideia horri artista batzuek «arteen marketinaren tranpa edo arriskua» deituko diote (Boorsma, 2006). Halaber, Evrardek (1992) arteen marketinaren funtzioa artelanentzako publikoa bilatzean datzala dio, eta ez merkatuarentzako produktu bat sortzean.

Ideia eta iritzi hauek ezagututa, eztabaidarako hurrengo galderak sortzen dira: Beharrezkoa al da marketina arteari egokitzea? Egon al daiteke marketin espezifiko bat kultura eta artearen sektorearentzat, beste sektoren aldean ezberdina dena? Horrela, Colbert eta Cuadradoren (2003) proposamena iritsiko da: marketina produktuan interesa duten merkatuko segmentuak aurkitzean datza, baita marketin mixeko aldagaiak ezartzeko ere. Horrela, kontsumitzaile kopuru nahikoa erakartzea lortuko da, horiek produktuarekin kontaktuan jarri eta erakundearen helburu kulturalak lortu eta misioa bete ahal izango da. 
Colbert eta Cuadradok (2003) arte eta kulturaren marketin-eredu zehatza proposatzen dute, marketin tradizionalaren aldean ezberdina dena. Haien ustetan marketin orokorrak ez du artearen errealitatea modu egokian islatzen; izan ere, prozesuak ezberdinak dira: marketin-eredu tradizionala bezeroen behar eta desioetan oinarritzen da, eta artearena, berriz, artistaren sormen eta inspiraizoan.

Ikuspegi sinple batetik, marketin tradizionalak kontsumitzaileen beharrak ezagutu eta horiek ahalik eta hoberen asetzeko merkatuko informazio-sistemak erabiltzen ditu, ondoren marketin mixeko lau elementuak finkatu ahal izateko (produktua, prezioa, banaketa eta komunikazioa). Bestalde, arteen marketinean, merkaturatze-prozesua behin produktua bukatuta dagoenean hasiko da. Horrela, produktua izango da abiapuntua, eta ez merkatua. Beraz, artelanetik abiatuta, hurrengo esteka merkatu potentziala bilatzea izango da, eta behin identifikatuta, marketin mixeko hiru elementuak (prezioa, banaketa eta komunikazioa) zehaztuko dira, produktuaren politika kontuan hartu gabe. Ikuspegi honek produktua marketin mixeko elementuetatik kanpo uzten du, eta, ondorioz, marketinaren lanetatik kanpo. Bezero edota kontsumitzaileetan oinarritutako ikuspegia (merkaturako orientazioa) ez litzaioke lan artistikoari aplikatu behar, marketina soilik prezio, komunikazio eta banaketa-lanetarako erabili beharko litzateke.

Colbert eta Cuadradoren iritziz (2003), produktu kulturala ez da merkatuaren beharrak asetzeko sortzen, eta, beraz, produktuarekiko erakarriak sentitzen diren kontsumitzaileak bilatu behar dira. Ikuspegi horrek esan nahi du marketina eta kreazio artistikoak independenteak direla, bakoitzak bere logika propioak dituelarik. Era berean, horrek esan nahi du arteen marketinaren lanak ez duela emaitza artistikoan eraginik, ezta aldaketarik eragiten ere. 1. eta 2. irudietan marketin tradizionalaren eta arteari aplikatu beharreko marketinaren ereduak azaltzen dira.

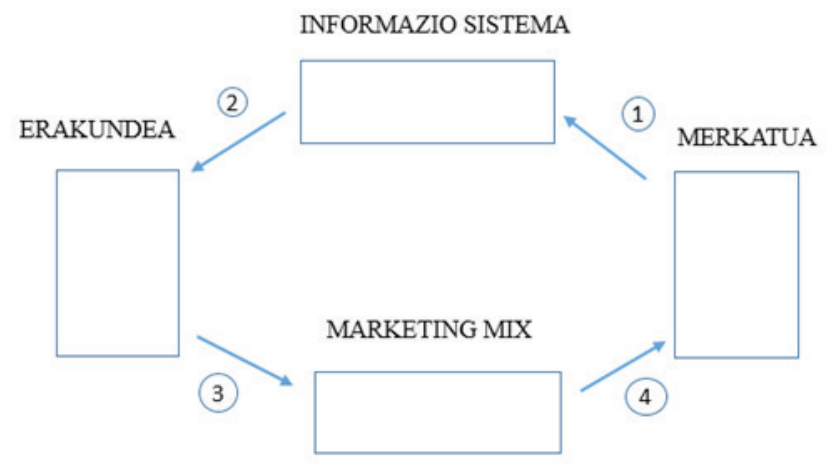

\section{1. irudia. Marketin tradizionalaren eredua.}

Iturria: Colbert eta Cuadrado (2003: 28). 


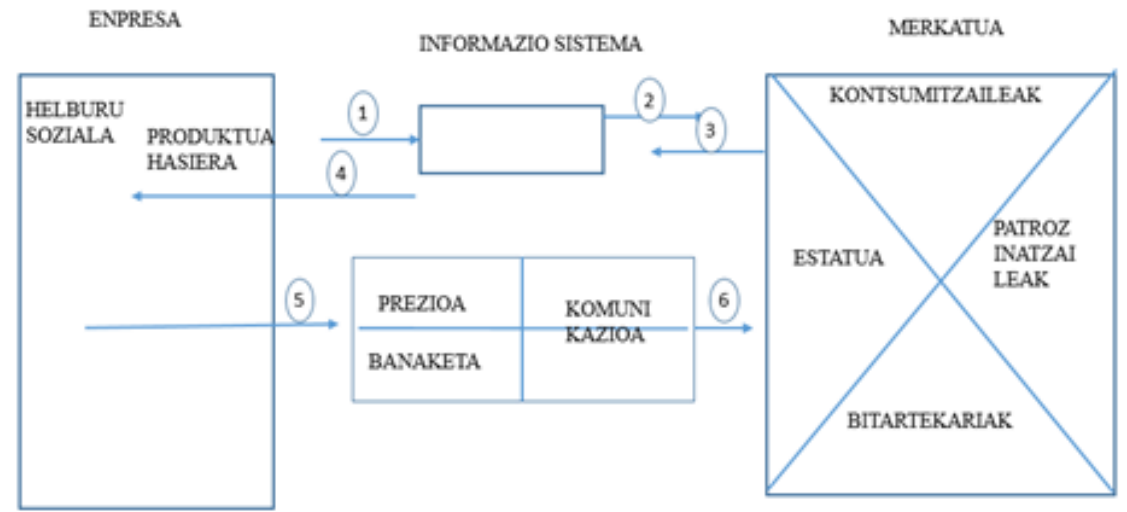

2. irudia. Arteen eta kulturaren marketinaren eredua.

Iturria: Colbert eta Cuadrado (2003: 29).

Beste azterketa batzuek (Kotler eta Scheff, 1997; Kolb, 2000; Kotler eta Scheffren, 2004) artearen arloan produktuari eman beharreko garrantzia azpimarratzen dute idatzitako artikulu akademikoetan ikus daitekeen moduan. Arteen marketinak honako galderak aditzera eman beharko lituzke lehenik: Zein da kontsumitzailea? Zerk ematen dio balioa kontsumitzaileri? Nola handitu daiteke bezeroek jasotako balioa? Orokorki esanda, autore horiek artistaren sormen askea eta kontsumitzailearen eta artelanaren arteko independentzia defendatzen dute, baina aldi berean azpimarratzen dute horrek ez duela esan nahi marketinak soilik produktuari bideratuta egon behar duenik. Marketinaren erabilerak kontsumitzaileen beharren eta integritate artistikoaren arteko oreka bat bilatu behar du.

Eboluzio honen azken urratsa, ikertzaile talde baten eskutik dator (Solomon, 2004; Boorsma, 2006). Horiek marketina filosofia bezala antzematen dute (merkaturako orientazioa) eta marketinaren funtzioa ezin dela ekoizpen-prozesu artistikotik at geratu adierazten dute, ezpada prozesuaren jarduera guztietan presente egon behar duela. Kontsumitzailea subjektu pasibo gisa kontsideratzeari utzi eta lanaren ekoizpenaren parte izan behar duela argudiatzen dute. Solomonek (2004) produkzio-sistema kulturalaren kontzeptua ezartzen du, non produktu artistikoa sortu eta merkaturatzen duten indibiduo taldeak eta erakundeak sistemaren parte diren. Sistema horrek hiru azpisistema ditu: kreatiboa, produktu berriak sortzen dituena; kudeaketa, produktu berri horiek aukeratu, ekoiztu eta banatzen dituena, eta, azkenik, komunikazioa, produktuaren atributuei esanahia ematen diena. Autore horren arabera, marketinak praktika gisa hiru azpisistemetan presente egon behar du, produktua sortzeko erabakia azken finean merkatuan oinarriturikoa izango delarik. Halaber, Boorsmak (2006) artelanaren produkzio-fasean kontsumitzailearen papera ezinbestekoa ikusten du. Artearen ikuspegi erlazionala aipatzen du, non kontsumitzailea ko-produktore bihurtzen den. Horrek esan nahi du lan artistiko batek bere funtzioa bete dezan audientziaren aldetik meritu artistikoa jaso behar 
duela, artea ez baita objektu bat, ezta akzio bat ere; ordea, publikoak kontsideratua izan behar du. Ikuspegi erlazionalak eragin nabarmena du arteen marketinean. Kontsumitzailea ko-produktore gisa jartzeak rolen berrantolaketa dakar eta, beraz, bezeroak ezingo dira kontsumitzaile soiltzat hartu. Gainera, ideia horren arabera, marketinak ez ditu bezeroen beharrak asetu behar, baizik eta horien sormengaitasunera bideratua egon beharko du.

Laburbilduta, Boorsmak (2006) lau baldintza proposatzen ditu arteen marketinaren aplikazioari begira: (1) Kontsumitzailea artelanaren ko-produktorea izango da ekoizpen-prozesu osoan zehar, baina inondik ere ez da produktuaren formaren kodiseinatzailea izango. (2) Arteen marketinaren helburua izango da kontsumitzaileari funtsezko balioa emanez esperientzia artistikoaren euskarria izatea eta aldi berean kontsumitzaileari esperientzia artistikoa erraztea. (3) Artearen kontsumitzaileen segmentu-aukeraketak helburu artistikoetan oinarrituta egon behar du. (4) Erakunde kulturalek ez dute euren garapena emaitza ekonomikoetan soilik neurtu behar, esperientzia artistikoa kontuan hartu behar dute, helburu artistikoak beteaz. Baldintza hauek kontuan hartuta, arteen marketina honela defini daiteke: «Bezero talde batekin egindako trukearen estimulazioa da, esperientzia artistikoaren ko-kreazioan oinarritutako zerbitzua eskainiz, bezeroekin harremanak eraiki eta mantendu ahal izateko, haientzako balioa sortuz eta horrela helburu artistikoak lortu».

\subsection{Artearen ikuspegi erromantikoaren eta marketinaren arteko oreka}

Gero eta ahots gehiagok merkatura bideraturiko marketina artearen arloan ere erabili behar dela diote, hau da, marketinak produktu artistikoen sortze- eta merkaturatze-prozesuan presente egon behar duela. Hala ere, bi iritzi kontrajarrien arteko gatazkak jarraitzen du. Flores et al. (2010) kontziente dira ezin dela artearen arloan marketina era zorrotzean erabili, kontsumitzaileen beharretatik abiatzea egokia ez delako, artistaren ikuspegi erromantikoa eta espresio artistikoa diseinu eta kreaziotik kanpo geratuko liratekeelako. Horren arriskua da produkzio kulturala soilik eskariak eskatzen duenaren baitan sortzea, eta ondorioz, manifestazio artistiko askoren desagerpena. Pentsaera horren arabaera, ulergarria da marketinaren erabilera soilik produktua amaitua dagoenean defendatzen dutenen ideia. Hala ere, horrek zera dakar: marketinari bigarren mailako zereginak uztea eta kontsumitzaileen beharrengandik urruntzea. Horrela, marketina enpresaren logika osotik at geldituko litzateke. Hori dela-eta, Flores et al.-ek (2010) artearen sektorera bideratutako marketin berezi baten beharra ikusten dute.

Caust (2003) eta Nielsenek (2003) «merkatuaren miopiarekiko»1 ezberdin pentsatzen dute, enpresa- eta merkatu-ikuspegiak meritu artistikoarekin bukatzeaz gain, audientziak nahi ez duen produktua ekoiztea ekar dezakeela diote. Flores et al.-en arabera (2010), marketina sormen-prozesuan erabiltzeak ez du manifestazio artistikoaren aurka egiten, alderantziz, prozesu hori marketinaz elikatzen da. Pentsamendu postmodernoaren ildotik jarraituz, denak gara sortzaileak eta sortzaile bezala artista berrelikatu dezakegu.

1. Marketinarekiko miopia Levittek aipatu zuen lehen aldiz bere izen bereko artikuluan, eta marketina enpresa-estrategia moduan ez ulertzeari egiten dio erreferentzia (Levitt, 2004).

UZTARO 112, 5-18

Bilbo, 2020ko urtarrila-martxoa 
Kotler eta Scheff (2004) bat datoz marketinak artisten misio artistikoa lortzen lagundu behar duelako ideiarekin. Hau da, produktu artistikoaren eskaria izango den segmentua bilatzen lagundu behar du, artistaren eta publikoaren arteko interakzioak berrelikadura dakarrelako. Modu horretan eta Boorsmaren (2006) ikuspegia kontuan hartuta, kontsumitzaileen desirak betetzeko erabiliko litzateke marketina, eta beraz, marketina sormen-prozesuan erabili ahalko litzateke, baina manifestazio artistikoan eragin gabe.

Toghraee, Rezvani, Mobaraki eta Farsik (2018) arte-arlora aplikatutako marketin ekintzaileari buruz hitz egiten dute. Haien ustez, artistek marketin mix-eko lau P-ak erabili beharrean (product, price, promotion, place), ekintzailearen bost C-ak erabili beharko lituzkete: kontaktu-sarea eta komunikatzeko konpetentziak (contact network and communicating competency), edukia (content), kreatibitatea (creativity), balio kulturalak (culturla values) eta artelanaren sortzailea (creator of artwork). Autore horien ikerketaren arabera, artistak ekintzaile bihurtzen dira dituzten lan-baldintzak direla-eta. Hortaz, eskola eta unibertsitateek ekintzailetzarako prestakuntza eskaini beharko liekete.

Lee, Fraser eta Fillisek (2018) Eskoziako Arte Ederretako ikasle graduatu berriak elkarrizketatu zituzten, eta emaitzetan zera agertu zen: ezinbestekoa da Arte Ederretako ikasleak arte-merkatuetan trebatzea. Ikasle horiek, era berean, ekintzailetza-penstamoldean hezi beharko lirateke, eta prezio-teknikak erakutsi, ez baitakite zer prezio ezarri haien lanei. Era berean, azpimarratzen dute plataforma digitalek artistei aukera ematen dietela haien lana erakutsi eta sustatzeko, baita beste artista eta bezeroekin kontaktuan jartzeko ere.

Bestalde, arteen marketinaren literaturak dio erakunde batek arte-esperientziak eskain ditzakeela produkturaren «mamia» (core product) ${ }^{2}$ aldatu gabe, erakusketetan edo egikaritzetan adibidez (Mc Lean, 1997). Hori posible da handitutako produktuaren gain (bigarren mailakoa edo periferikoa) aldaketak eginez. Levitt (1983) izan zen eskainitako produktua lau mailatan sailkatu zuena: produktu mamia edo orokorra (core product), esperotako produktua (expected product), produktu hedatua (augmented product) eta produktu potentziala (potential product). Produktu mamia, oinarrizko produktu fisikoa da, adibidez telefono mugikorra. Esperotako produktua, produktu mamia erosketa-baldintza batzuekin, adibidez telefonoak duen garantia. Produktu hedatuak konpetentziarengandik ezberdintzeko aukera ematen duen eremua da, eta eremu hori da hain zuzen ere bezeroak hautemandako balioa handitzeko erabili behar dena. Mugikorraren kasuan, lapurreta edo apurketa baten aurrean aseguru bat kontratatzeko aukera izango litzateke, edota bi telefono-txartel (zenbaki) erabiltzeko aukera. Azkenik, produktu potentziala etorkizunean aldaketak jasateko aukera ematen duen eremua da, produktuaren garapena definitzen duena hain zuzen ere.

2. Produktu mamia Levittek (1983) sortutako kontzeptua da core product, oinarrizko produktua (Levitt, 1983). 


\section{Ondorioak}

Arteen edo kulturaren marketin kontzeptua lehenengoz sortu zenean, 70eko hamarkadan, artearen ideia erromantikoa hartu zen kontuan eta ez zen gaur egungo marketinaren filosofiaren ikuspegia erabiltzen. Artelan batez espero den balioa beste kontsumo-produktuena baino handiagoa dela pentsatzen zen, kuantifikatzeko zaila, eta merkatuak ez zuela eragin behar artistaren sormen-fasean, bestela artearen berezitasunekin apurtzea ekarriko lukeelako. 90eko hamarkadan, arte-arloan ere marketinaren filosofia erabiltzea defendatzen zuten ahotsak entzuten hasi ziren, eta momentu horretan hain zuzen ere, artearen ikuspegi erromantikoaren eta marketinaren erabileraren arteko talka sortu zen. Agerian gelditu ziren akademikoek zituzten bi ikuspegi nagusiak: marketina behin produktua amaituta dagoenean erabili behar dela (produkturako orientazioa), eta marketinak produktuaren diseinu- eta sortze-prozesuan ere presente egon behar duela (merkaturako orientazioa). Adituak arteen marketinaren bitartez bi ikuspegi horien arteko oreka bilatzen saiatu dira, artistaren sormena marketinaren eraginetik independente mantenduz, eta horrela artearen ideia erromantikoa eta marketinaren erabilera bateragarri bihurtu.

Arte-sortzaile ororen helburua bere lana saltzea dela esan daiteke. Artelanak erosle potentzialez osatutako merkatu batean saltzen dira. Hortaz, beharrezkoa da erosle potentzial horien ezaugarriak ezagutzea: zein artelan mota duten gustuko, noiz erosten duten, zer salmenta-kanal erabiltzen dituzten produktua aurkitzeko eta erosteko, zenbat ordaintzeko prest dauden eta abar. Horretarako, merkatua ezagutu beharra dago eta eskaintza kontsumitzaileen nahien arabera egokitu, horiek artistaren lana eros dezaten. Beraz, nolabait, kontsumitzaileak edo merkatuak artelanaren sortze-prozesuan kontuan hartu behar dira. Horrek ez du esan nahi artistaren sormenean eraginik izan behar duenik. Azken finean artistak etengabe jasotzen ditu estimuluak bere ingurutik, bere sormenean eragina izango dutenak. Inguru hori osotzen dute: egoera ekonomikoak, egoera politikoak, arte-kritikoen iritziek, beste artisten lanek, gazteen jokaerek... eta zergatik ez kontsumitzailearen jokaerak ere?, kontsumitzailea edo bezeroa kontuan hartzeak ez du esan nahi horiek eskatzen dutena bakarrik ekoiztu behar denik; baina bai haien gustuak, erosketa-ahalmena, bizitza-estiloa eta abar kontuan hartzea komenigarria dela. Gainera, horrek ez du zertan oztopatu artistak bere inspirazioaren baitan sortzea.

Beraz, artea betiere helburu den publiko batera bideraturik dagoela esan daiteke, merkatu osora ez bada ere, bai behintzat segmentu zehatz batera. Artistek beste artistengana jotzen dute, kritikoengana edo talde txiki batengana. Gizakiak erlazionatzeko beharra du, zerbaiten parte izatearena, eta ondorioz, artista batek publiko eta kritikoen errekonozimendua bilatzen du. Errekonozimendu hori lortzeko segmentu zehaz batengana zuzenduko da. Arteen marketinaren funtzioetariko bat segmentu hori ondo ezagutzea eta marketin mix-eko aldagaiak modu egoki eta koordinatu batean konbinatzea da, horrela marketin-ekintza eraginkorrak burutu ahal izateko. 
Egileak beharrezkoa ikusten du artistak merkatua ikertzea, ingurua aztertzeko, beste artistak ezagutzeko, bezeroak edo eskaria identifikatzeko eta talde homogeneoetan banatzeko. Modu horretan, haiengana era egokian iritsi ahal izango da eta arte-merkatuan artista bezala kokatzeko lagungarria izango zaio. Garrantzi berezia daukate marketin mix-aren banaketa eta komunikazioaren aldagaiek, beste artistekin, kritikoekin eta bezeroekin harremanak sortzen lagungarriak baitira.

Bestalde, egokia izango litzateke etorkizuneko artistak negozio eta marketinaren inguruan trebatzea arte-eskoletan. Gompertzek (2016) dioen bezala, artista batek arrakasta edukitzeko beharrezkoa da enpresa-ikuspegia izatea. Leonardo da Vincik esan zuen arrakasta duten pertsonak ez daudela gertakarien zain, baizik eta gertaerak bilatzen dituztela.

Halaber, webgune digitalek eskainitako aukerek garrantzi handia hartu dute bizi dugun era digital eta globalizatuan. Artean espezializatutako Marketplace-ak bide egokiak dira artelana publikoari erakutsi eta helarazteko. Marketplace batzuk dira Artelista, Artenet, SaatchiArt eta ArtDevian. Artelana erakusteko eta saltzeko aukeraz gain, beste artista batzuen lana ikusteko eta haiekin harremanetan jartzeko aukera ere ematen dute.

\section{Bibliografia}

American Marketing Association (2008): Definition of marketing marketing news, <https:// www.ama.org/the-definition-of-marketing> (Kontsulta 2008-2-29).

Arts Council of Great Britain. (1976): Report on special marketing projects in Sheffield, Bristol and Birmingham, Arts Council of Great Britain, Londres.

Arts G.L. (1989): Marketing resource pack: A guide to arts marketing for small and middle scale performing arts groups, Greater London Arts, Londres.

Auñamendi Eusko Entziklopedia (2018): Artearen esanahia, <http://aunamendi.euskoikaskuntza.eus/eu/bilatu/artea/10/> (Kontsulta: 2018-04-08).

Boorsma, M. (2006): «A strategic logic for arts marketing: Integrating customer value and artistic objectives», International Journal of Cultural Policy, 12.1, 73-92.

Caust, J. (2003): «Putting the "art" back into arts policy making: How arts policy has been "captured" by the economists and the marketers", The International Journal of Cultural Policy, 9.1, 51-63.

Colbert, F. eta Cuadrado, M. (2003). Marketing en las artes y la cultura, Editorial Ariel, Bartzelona, Espainia.

Diggle, K. (1976): Marketing the arts, City University, Londres.

Evrard, Y. (1992): “Culture et marketing: Incompatibilité ou reconciliation?», in F. Colbert eta C. Mitchell, C. (ed.), Première conference sur le gestion des arts, Actes de la conference, Montreal.

Flores, J.I.A.; Pérez, M.J.S. eta Blanco, V.F. (2010): «El marketing de la cultura y las artes: Una evolución», Revista Nacional De Administración, 1.2, 23-36.

Gompertz, W. (2016): Todos tenemos talento creativo. todos podemos ser artistas, <https:// elpais.com/cultura/2016/02/25/actualidad/1456425616_274508.html> (Kontsulta: 2019-04-15).

Harluxet (2018): Artearen esanahia, <http://www1.euskadi.net/harluxet/hiztegia. asp?sarrera=arte2> (Kontsulta: 2018-04-10). 
Hirschman, E.C. (1983): «Aesthetics, ideologies and the limits of the marketing concept», Journal of Marketing, 47.3, 45-55.

Klamer, A. (2016): «The value-based approach to cultural economics», Journal of Cultural Economics, 40.4, 365-373.

Kolb, B. (2000): Marketing cultural organisations: New strategies for attracting audiences to classical music, dance, museums, theatre and opera, Oak Tree Press, Dublin, Irlanda.

Kotler, P. (1999): «Political marketing-generating effective candidates, campaigns, and causes", Handbook of political marketing, Sage Publications.

Kotler, P. eta Scheff, J. (1997): Standing room only: Strategies for marketing the performing arts, Harvard Business School Press.

, (2004): El marketing de las artes escénicas, Fundación Autor.

Lee, H.K. (2005): «When arts met marketing: Arts marketing theory embedded in romanticism», International Journal of Cultural Policy, 11.3, 289-305.

Lee, B.; Fraser, I. eta Fillis, I. (2018): “Creative futures for new contemporary artists: Opportunities and barriers», International Journal of Arts Management, 20.2, 9-19.

Levitt, T. (1983): The marketing imagination, Free Press, New York, NY.

, (2004): «Marketing myopia», Harvard Business Review, 82.7/8, 138-149.

Maitland, H. eta Meddick, J. (1990): The marketing manual of the arts, Arts Council.

Mc Lean, F.C. (1993): «Marketing in museums: A contextual analysis», Museum Management and Curatorship, 12.1, 11-27.

Melillo, J. (1983): Market the arts!, Foundation for the Extension and Development of the American Professional Theatre.

Mokwa, M.P.; Dawsom, V.M. eta Prieve, E.A. (1980): Marketing the arts, Praeger Publishers, New York.

Nielsen, H. (2003): "Cultural policy and the evaluation of quality», International Journal of Cultural Policy, 9, 237-245.

Peralta, D. (2013): Arte y marketing ¿dos mundos opuestos?, <https://davidperalta.es/arte-ymarketing-dos-mundos-opuestos/> (Kontsulta: 2019-04-5)

Raymond, T. eta Greyser, S. (1978): «The business of managing the arts», Harvard Business Review, 56, 123-132.

Robbins, G. eta Verwey, P. (1982): The TMA marketing manual, Theatrical Management Association, Londres.

Rodger, L. (1987): Marketing the visual arts: Challenge and response, Scottish arts council, Edinburgo, Erresuma Batua.

Schaeffer, J. (1998): Think art theory and practice in the art of today.

Scheff, J. eta Kotler, P. (1996): «Crisis in the arts: The marketing response», California Management Review, 39.1, 28-52.

Searles, P.D. (1980): «Marketing principles and the arts», Marketing the arts, Praeger, New York, 65-69.

Solomon, M.R. (2004): Consumer behaviour: Buying, having and being (6. ed).

Toghraee, M.T.; Rezvani, M.; Mobaraki, M.H. \& Farsi, J.Y. (2018): «Entrepreneurial marketing in creative art based businesses», International Journal of Management Practice, $11.4,448-464$.

Voss, G.B., eta Voss, Z.G. (2000): «Strategic orientation and firm performance in an artistic environment», Journal of Marketing, 64.1, 67-83.

Walker, S.E.; Etzel, M. eta Stanton, W. (2007): Fundamentos de marketing, McGraw Hill.

Wyatt, M. (1983): Marketing guidelines, North West Arts, Manchester. 

